\title{
Development of professional competence of future foreign language teachers in inclusive education through profession-based volunteering
}

\author{
E.N. Kvasyuk ${ }^{1 *}$ \\ ${ }^{1}$ Murmansk Arctic State University, Murmansk, Russia
}

\begin{abstract}
The existing modern trends, associated with the need for a wider inclusion of children with disabilities in society, actualize the problem of the formation of inclusive competence of teachers, and the teachers of foreign languages are not an exception. We should start the process of development of this professional competence at university level. The article aims to state the importance of the acquiring inclusive professional competence in teaching children with special educational needs by university students, studying at the department of foreign languages, through profession-based volunteering. federal state educational standard of higher education provides the universities with the list of necessary competences that should be developed in educational process. These competences can be divided into groups: general, basic, special and specific competences. The object of the research is the process of inclusive competence development of future foreign language students of Murmansk arctic state university through profession-based volunteering. The article analyzes the results of the survey conducted in Murmansk arctic state university.
\end{abstract}

\section{A problem statement}

This article is motivated by the topicality of the problem of the development of inclusive competence of university students. Much of the literature concerning professional competences does not focus on the ability of teachers of ordinary schools to work with handicapped students. In contrast, the main purpose of this article is to illustrate some strategies and results of the process of the development of inclusive competence of future foreign language students of Murmansk arctic state university through profession-based volunteering.

At the present stage of development of society, one of the main and most relevant directions of the reform of the education system in the Russian Federation is "inclusive education", which acts as the only internationally recognized tool for realizing the right of every person to education. Inclusive education is ensuring equal access to education for all

*Corresponding author: ipcs-profped@yandex.ru 
learners, taking into account the diversity of special educational needs and individual opportunities. Such training is based on the fact that all students, despite their physical, intellectual, ethnic, confessional and other characteristics, as well as the socio-economic status of the family, have equal rights and are included in the general education system they are brought up and trained together with their peers, where their special educational needs are taken into account.

Inclusive education is not compulsory for children with disabilities, but it allows the child to preserve his usual social environment $[1,2]$. Early socialization has a beneficial effect on the formation of the personality of children with disabilities and their adaptation in real life.

If the society wants to implement inclusive education in practice efficiently, we should first solve a number of problems associated not only with the material base, but also with the different positions of members of society. [3,4] One of the main issues is unpreparedness of teachers without special education to carry out their professional activities in the new conditions. Considering that a handicapped child can get the opportunity to freely choose an educational institution, each teacher must have a certain level of inclusive competence formation as a component of his professional competence [5, $6,7,8]$.

Competence is traditionally understood as socially determined requirements for the level of training of a specialist, a specific, given content of knowledge and experience that must be mastered in order to be professional, and competence as an integrative quality of a person that determines the level of compliance with these requirements.

Nowadays special professional competence of a teacher comprises the inclusive competence which determines the ability of any teacher to work in the sphere of inclusive education, building the educational process according to different needs of students with disabilities. Thus prepared specialists will be able to include handicapped pupils into the environment of educational organization and create conditions for his/her development and self-development $[9,10]$.

In the structure of inclusive competence, scientists distinguish motivational, cognitive, operational and reflexive components. The motivational component of the inclusive competence of a teacher is determined by deep personal interest to implementation of inclusive teaching techniques, a positive attitude to teaching children with disabilities in the environment of normally developing peers, a set of motives (cognitive, professional, social, personal development and self-affirmation, etc.) [11].

The cognitive component of the inclusive competence of a teacher implies to cognitive competence, which means the ability to think pedagogically, perceive and reproduce at the right time, an impulse for a solution to theoretical and practical tasks of inclusive education. This key competence is based on scientific professional and pedagogical knowledge of innovative integration processes in the field of special education; foundations of personality development; pedagogical and psychological foundations of training and education; anatomical and physiological, age, psychological and individual characteristics of normal students and students with various developmental disorders; foundations of pedagogical management of the pupils' self-development process; the basic laws of interaction between society and a person with developmental disabilities.

The operational component of the inclusive competence of a teacher includes operational competencies, which are defined as the ability to perform specific professional tasks in the pedagogical process and represent the mastered methods and experience of pedagogical activity necessary for the successful implementation of inclusive education, resolving emerging pedagogical situations, methods of independent and mobile solution of pedagogical problems, search and research activities. 
The reflexive component of the inclusive competence of the teacher includes reflexive competence, manifested in the ability to reflect on the activity in the conditions of preparation and implementation of inclusive education.

Different scientists consider different ways of acquirement of teachers' professional competence in inclusive $[12,13,14,15]$. The majority of them come to the conclusion that the process of its development can be efficient only through, firstly, professional experience in the sphere of education when the specialist has to solve different pedagogical tasks and perform various professional activities. Secondly, to acquire professional competence, a teacher should develop readiness to work in different professional circumstance. And the third component of the process of the development of professional competence is personality which possesses special traits to implement professional tasks in the sphere of inclusive education $[16,17]$.

When the teacher has acquired inclusive professional competence he is able to do the following:

- determine the level of the development of the class at various levels of inclusive education;

- foresee the results of certain pedagogical actions;

- design appropriate educational activities through correct goal setting and competent planning of the teaching activities, taking into account the different educational needs of students, varying the forms, methods and means of teaching;

- establish constructive relationships with the subjects of the pedagogical process, contributing to the effective implementation of inclusive education;

- implement methods and techniques of inclusive education for children with different educational needs and various types of developmental disabilities;

- study, analyze pedagogical phenomena, carry out experimental work [18, 19, 20].

Based on the fact that inclusive education has not yet been introduced into the wide practice of educational organizations, but is enshrined in legislation, and working teachers do not have a high level of inclusive competence, it seems appropriate to start the development of this professional competence at the university level. The curriculum of higher educational programme "Pedagogical education. Teacher of foreign languages (English and German)" of Murmansk arctic state university (MASU) does not include modules for developing competencies in the context of the implementation of inclusive education of foreign language teachers.

The only possible way for them to acquire inclusive competence seems to be the use of so called profession-based volunteering when students get the opportunity to work with pupils with disabilities. Profession-based volunteering is understood as an innovative type of activity aimed at the practical training of students, presented in the form of a system of independent practical tasks and designed to qualitatively complement the existing level of students' training, to increase their professional activity through the provision of free aid to institutions, charitable and public organizations in the implementation of activities aimed at solving urgent problems requiring the participation of volunteers [21, 22]. Teaching the English language to children with disabilities is especially important today due to the fact that it is important not only to give the child as much knowledge as possible, but to provide him with general cultural, personal and cognitive development, to equip him with the ability to learn $[23,24]$. Knowledge of the English language, even at an elementary level, helps children to socialize, become more independent, not to experience difficulties in communicating with peers. Thus, the main task of inclusive education is realized here - the socialization of handicapped children.

Thus the department of foreign languages of MASU organized a student society for profession-based volunteering "Inclusive English" which gives the students - future English teachers the opportunity to develop motivational, cognitive and reflexive 
components of inclusive competence. The main goal of our student society is to form students' professional and general cultural competencies within the framework of voluntary additional scientific and educational work. The main tasks are: to associate university students - future English teachers with an interest in teaching a foreign language for children with special needs; to develop of volunteer activities for conducting classes and extracurricular activities in English with children with developmental disabilities; to hold seminars to discuss work experience and new methods of work with handicapped pupils; to cooperate with charity organizations who work with disabled children.

The number of students-volunteers who want to take part in our student society and be prepared for future work as foreign language teachers is growing every year. Nowadays we have 25 active participants. There are different forms of work in our student society "Inclusive English": group work, individual work, consultations, online and offline classes. Students teach English to groups of pupils with disabilities with different levels of English, using the methods and teaching techniques according to special needs of pupils, the socalled differentiating approach. For example, children with hearing impairment, attention and speech disorders learn better with visual material - these are pictures, presentations, ebooks and assignments; at the senior stage - small diagrams, reference tables, adapted texts in the form of comics. When teaching visually impaired children, listening is the most effective approach, since for students with bad eyesight listening becomes the only way to get education and master the English language. Also at our classes we try to create a favorable psychological environment in the group of disabled pupils. Successful situations in each lesson helps the children with disabilities feel the joy of a small but well-done assignment. What is also important is the use of health-saving technologies and an adapted educational program, taking into account the characteristics of psychophysical development and the capabilities of handicapped children.

Based on the analysis of the survey results of 50 students of Murmansk arctic state university and the conducted experiment, the author examines the efficiency of the used techniques of development of students' inclusive professional competence. The findings support the prediction of the efficiency of the use of profession-based volunteering in gaining professional experience, developing readiness and personality traits for inclusive work.

\subsection{The objective of the work}

We have conducted a survey in order to study the benefits of using profession-based volunteering in development of inclusive professional competence of students of foreign language department. Fifty students studying on the training direction "Pedagogical education. Foreign languages" were interviewed.

The experiment had two stages and was conducted in the beginning and the end of 2019-2020 academic year. The students did not have any experience of working with disabled children before the survey. 25 of the respondents have later become the volunteers of student society "Inclusive English" and they form Group 1, the rest of the respondents form Group 2. We were interested to find out the possible changes in the development of the level of students' inclusive professional competence through profession-based volunteering.

Throughout the year the students volunteered in the student society to develop motivational, cognitive, operational and reflexive components of inclusive competence. Theoretical material about work with handicapped children was given by the experienced teachers. Thus they discussed the essence of special education; the current state of the problem of working with children with special educational needs; features of the organization of special education systems in different countries; essence of inclusive 
education; problems and prospects for the implementation of inclusive education in Russia; peculiarities of teaching and upbringing of children with various disabilities; the essence of inclusive teacher competence. The theory was supplemented with a lot of practical classes in groups and online individual consultations.

The study adopted such research method as the questionnaire, since the method is the most suitable for collecting input data and consistent with the goals and objectives of the study. The sampling includes students from Murmansk Arctic State University (aged 1722).

The students were asked to write their opinion on the following issues:

The questionnaire combined open-ended questions and multiple-choice questions with predefined answers offering respondents the possibility to choose and rank among several options or the possibility to grade on a "very low" to "very high" scale. For these questions, an optional space was provided to elaborate on the answer. This open part is considered of great importance for a survey of this kind as it contributes to improving the interpretation of its overall results and provides with additional valuable material.

The survey had two stages at which we studied motivational, cognitive, operational and reflexive components of inclusive competence of students. The questionnaire consisted of the following questions:

1. What is your attitude to teaching children with disabilities? Why?

2. Are you interested in inclusive education? Why/Why not?

3. What are the peculiarities of work with impaired pupils at English lessons?

4. Do you know any inclusive teaching techniques at English classes? (Can you name them)

5. Can you implement methods and techniques of inclusive education for children with special educational needs?

6. Do you think that inclusive professional competence is important for future foreign language teachers?

7. How does profession-based volunteering in student society "Inclusive English" can help you in your personal and professional growth?

The given questions correlate with the aim of our research and let us find out the level of students' professional competence. The respondents took the task seriously and gave full answers. The findings of the questionnaire convinced us that the profession-based volunteering is considered by the students as necessary and efficient in development of inclusive competence.

\section{Materials and the results of the research}

The respondents were divided into groups. Group 1 comprised the students - volunteers of the student society "Inclusive English". Group 2 comprised the students of the department of foreign languages who are not volunteers.

Answering the first question that reflects motivational component of the inclusive competence, the majority of the respondents $(70 \%)$ mentioned the positive attitude to teaching children with disabilities. At the same time in the beginning of the academic year they could not give any appropriate explanation why they think so. $30 \%$ of the students gave a negative answer because they are sure that only teachers with special diffectological education should work with impaired pupils. At the second stage of the experiment the respondents of group 1 explained that they are positive about teaching children with disabilities because inclusive education is a modern educational tendency nowadays and any teacher should possess knowledge and experience in this sphere.

Analyzing the answers to the second question (Are you interested in inclusive education? Why/Why not?) we can notice the same situation: the respondents have 
motivation to such work but they cannot explain why because they lack knowledge on this issue. The students who volunteered during the year at the second stage could mention that when you try working with disabled children and see their progress, you feel reward and develop your self-esteem.

When asked about the peculiarities of work with impaired pupils at English lessons only 12 students could specify individual approach to pupils with disabilities. It proved a low level of cognitive component of inclusive competence of students. At the second stage the respondents from group 1 were aware of the featured of inclusive work and could enumerate some of them.

Answering the fourth question that reflects cognitive component of the inclusive competence, none of the respondents at the first stage of the survey could name any specific inclusive teaching techniques for English classes. It can be explained by lack of knowledge and experience in this sphere because after the volunteer work with impaired pupils the respondents could specify different methods of teaching visually impaired children, pupils with hearing impairment, attention and speech disorders and other disabilities.

Only at the second stage of the survey the respondents from group 1 could answer positively to the next question (Can you implement methods and techniques of inclusive education for children with special educational needs) because they managed to get some experience of such unusual work. This question reflects operational component of the competence as it helps to study the ability of students to perform specific professional tasks in the sphere of inclusive education.

Questions \#6 (Do you think that inclusive professional competence is important for future foreign language teachers?) and \#7 (How does profession-based volunteering in student society "Inclusive English" can help you in your personal and professional growth) aimed to evaluate the reflexive component of the inclusive competence of future foreign language teachers as they show the ability to reflect on the activity in the conditions of preparation and implementation of inclusive education. The majority of the students answered that inclusive competence is important nowadays because it helps to plan your teaching according to the needs of all pupils in the class taking into consideration their talents or disorders.

All the volunteers from our student society "Inclusive English" mentioned that profession-based volunteering helps them to develop their abilities and competences not only in professional sphere, but personal and social.

The number of correct answers to the given questions let us find out the levels of the development of inclusive competence of the respondents.

Table 1. Level of the development of inclusive professional competence of students in the beginning of academic year 2019-2020.

\begin{tabular}{|l|l|l|l|}
\hline & Low level & Average level & High level \\
\hline $\begin{array}{l}\text { Group 1 } \\
(25 \text { respondents })\end{array}$ & $72 \%$ & $28 \%$ & - \\
\hline $\begin{array}{l}\text { Group 2 } \\
(25 \text { respondents })\end{array}$ & $80 \%$ & $20 \%$ & - \\
\hline
\end{tabular}

According to the fist diagnostics the students of both groups do not have a definite idea of inclusive education of children with disabilities so none of them got high level of the competence. 
Table 2. Level of the development of inclusive professional competence of students in the end of the academic year 2019-2020.

\begin{tabular}{|l|l|l|l|}
\hline & Low level & Average level & High level \\
\hline $\begin{array}{l}\text { Group 1 } \\
(25 \text { respondents })\end{array}$ & - & $60 \%$ & $40 \%$ \\
\hline $\begin{array}{l}\text { Group 2 } \\
(25 \text { respondents })\end{array}$ & $68 \%$ & $32 \%$ & - \\
\hline
\end{tabular}

Looking at the results of the second diagnostics it can be noted that most of the students of the first group have significantly increased the level of inclusive competence. More than half of the respondents reached the average level $-60 \%, 40 \%$ of the students reached the high level. We can see the results in figure 1 .

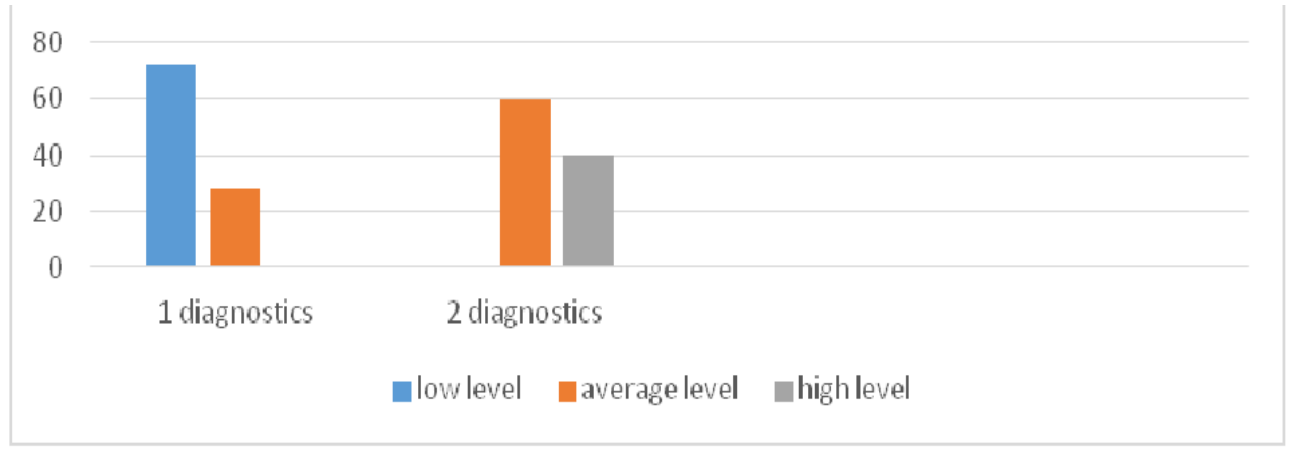

Fig. 1. Changes of the levels of the development of inclusive competence of studens-volunteers.

According to the data we can see that a lot of respondents from group 1 have a high level of inclusive professional competence after the experimental work. The students who took part in the work in our student society "Inclusive English" have developed motivational component of the inclusive competence which means that they are ready to work with impaired pupils and teach them English in the future after graduation from the university. They have been volunteering in in this sphere for more than a year already and got necessary experience of teaching handicapped pupils English. Moreover, on the cognitive and operational levels the students of the department of foreign languages of Murmansk arctic state university had an opportunity to gain theoretical background which helps to structure the work with impaired children properly and to use various efficient forms, methods, educational tools, technologies and conditions of inclusive education. On the reflexive level we can conclude that the students find it important and useful to take part in profession-based volunteering which will be beneficial not only for the professional growth but for the whole personal development.

\section{Conclusions}

All in all, evolution towards inclusive education makes it impossible for the teachers not to be involved in the process. Inclusive education is designed to improve the quality of education, upbringing and socialization of all children without exception and at all classes (English as a second language is not an exception). That is why the development of inclusive professional competence is one of the most important tasks in modern educational process and should be included in the university curriculum. Inclusive professional competence comprises motivational, cognitive, operational and reflexive components which should be developed still at the university level. 
The high level of development of inclusive competence of future foreign language teachers will allow them to effectively carry out pedagogical activities, ensuring that not only children with disabilities, but also other categories of children with learning difficulties, for example, migrant children, are included in the environment of a general education school. Modern demanded specialists should possess not only deep knowledge and skills in the field of education, owning a modern interactive teaching methods and education of children, but also personality, patience and tolerance for people, regardless of their physical and other features.

\section{References}

1. C. Henry, S. Namhla, Scientific African, Volume 8, 89-102 (2020)

2. L. Neal-Boylan, M. Miller, Teaching and Learning in Nursing, 15, 237-240 (2020)

3. N. Spörer, J. Lenkeit, S. Bosse, A. Hartmann, A. Ehlerta, M. Knigge, International Journal of Educational Research, 103, 101-113 (2020)

4. B. Baimenov, Z. Bekov, Z. Saule, Procedia - Social and Behavioral Sciences, 205, 577-583 (2015)

5. M. Metzger, J. Taggart, Journal of Professional Nursing, 36, 229-235 (2020)

6. D. Bjekić, S.Obradović, M. Vučetić, M. Bojović, Procedia - Social and Behavioral Sciences, 128, 128-133 (2014)

7. A. Wullschleger, A. Garrote, S. Schnepe, L. Jaquiéry, E.Moser, Contemporary Educational Psychology, 60, 356-367 (2020)

8. C. Dumitriu, G. Dumitriu, I.C. Timofti, Procedia - Social and Behavioral Sciences, 116, 864-868 (2014)

9. E.M. Kuznetsova, L.V. Mikhaleva, Procedia - Social and Behavioral Sciences, 200, 278-282 (2015)

10. A. Peacock, B. Rawson, International Journal of Educational Development, 21, 79-92 (2001)

11. S. Jovanova-Mitkovska, D. Hristovska, Procedia - Social and Behavioral Sciences, 28, 573-578 (2011)

12. P. Sládeka, R. Bednárová, T. Miléř, Procedia - Social and Behavioral Sciences, 12, 145-149 (2011)

13. B.M. Nandjui, D.A. Alloh, B.K. Manou, J.A. Bombo, A.Pillah, Annales de Réadaptation et de Médecine Physique, 51, 109-113 (2008)

14. V. Carrière, Procedia - Social and Behavioral Sciences, 46, 701-705 (2012)

15. N. Gokool-Baurhoo, A. Asghar, Teaching and Teacher Education, 79, 17-27 (2019)

16. E. Cappe, M. Bolduc, N. Poirier, M.A. Popa-Roch, E. Boujuta, Teaching and Teacher Education, 67, 498-508 (2017)

17. P. Conceição, M.V. Heitor, Technological Forecasting and Social Change, 69, 641$651(2002)$

18. A.M.A. Love, M.D. Toland, E.L. Usher, J.M. Campbell, A.D. Spriggs, Research in Developmental Disabilities, 89, 41-50 (2019)

19. E.J. Short, C. Schatschneider, C. Cuddy, S.W. Evans, D.M. Dellick, L.A. Basili, Contemporary Educational Psychology, 16, 139-153 (1991)

20. Z. Movkebaieva, I. Oralkanova, E. Uaidullakyzy, Procedia - Social and Behavioral Sciences, 89, 549-554 (2013) 
21. A. Morris, Journal of Nutrition Education and Behavior, 51, 1-15 (2019)

22. A. Magyar, A. Krausz, I.D. Kapás, A. Habók, Heliyon, 6, 104-111 (2020)

23. W. Vantieghem, I. Roose, E. Gheyssens, J. Griful-Freixenet, K. Keppens, R. Vanderlinde, K. Struyven, P.V. Avermaet, Studies in Educational Evaluation, 67, 136$141(2020)$

24. K. McAllum, Management Communication Quarterly, 28 (1), 84-110 (2014) 